\title{
Climate change poses health threats in Arctic
}

A s climate change and receding sea ice open new corridors into previously remote communities in the Arctic, residents can expect a wave of social ills and the introduction of diseases that may be as devastating as the Spanish flu was to those living in the North in the early 1990s, experts say.

"A second wave of tumultuous change" is threatening Inuit health, says Sheila Watt-Cloutier, Inuit activist, former international chair of the Inuit Circumpolar Council and 2007 Nobel Peace Prize nominee for her work in linking climate change to human rights.

"The overall invasion of new species, of new tourists, of workers who are on these ships are concerns for everybody living up there in terms of safety, security and health," adds Watt-Cloutier, currently a visiting scholar at Mount Allison University in Sackville, New Brunswick, and one of the architects of the 2001 United Nations Stockholm Convention that prohibited the use of a class of toxic chemicals called persistent organic pollutants (POPs) in the Arctic because they accumulate in the food chain and pose a health risk to Inuit peoples, many of whom still rely on hunting, trapping and fishing. "With climate change, as warming of the Arctic (carbon) sink increases, there is the distinct possibility that more POPs that are dormant at the bottom of the Arctic sink will be re-released back into the environment," she says.

Watt-Cloutier and others are also concerned about the threat of insect-borne and other zoonotic infectious diseases.

"Within Canada, we're seeing the emergence of certain zoonotic diseases," such as West Nile virus and Lyme disease," says Dr. Manisha Kulkarni, an epidemiologist with the Public Health Agency of Canada's Centre for Foodborne, Environmental and Zoonotic Infectious Diseases. In the North, "the risk of infection is greater in the human population due to the increased contact with wildlife that they have through their cultural practices," such as hunting, fishing and skinning.

There are both biomedical and psychological consequences from widescale environmental and cultural changes, James Ford, assistant professor of geography and head of the Climate Change Adaptation Research Group, at McGill University in Montréal, Quebec, writes in an email. "We are seeing enhanced dangers associated with sea ice and constrained access to traditional foods at key times of the year. Both are linked to mental health, as the act of hunting and consuming traditional foods is culturally very important, and nutritional well-being as the health benefits of consuming traditional foods is widely known."

The health impact from a major change in diet can be enormous, says Elisapee Sheutiapik, president of the nonprofit organization, Pauktuutit Inuit Women of Canada. "In some commu-

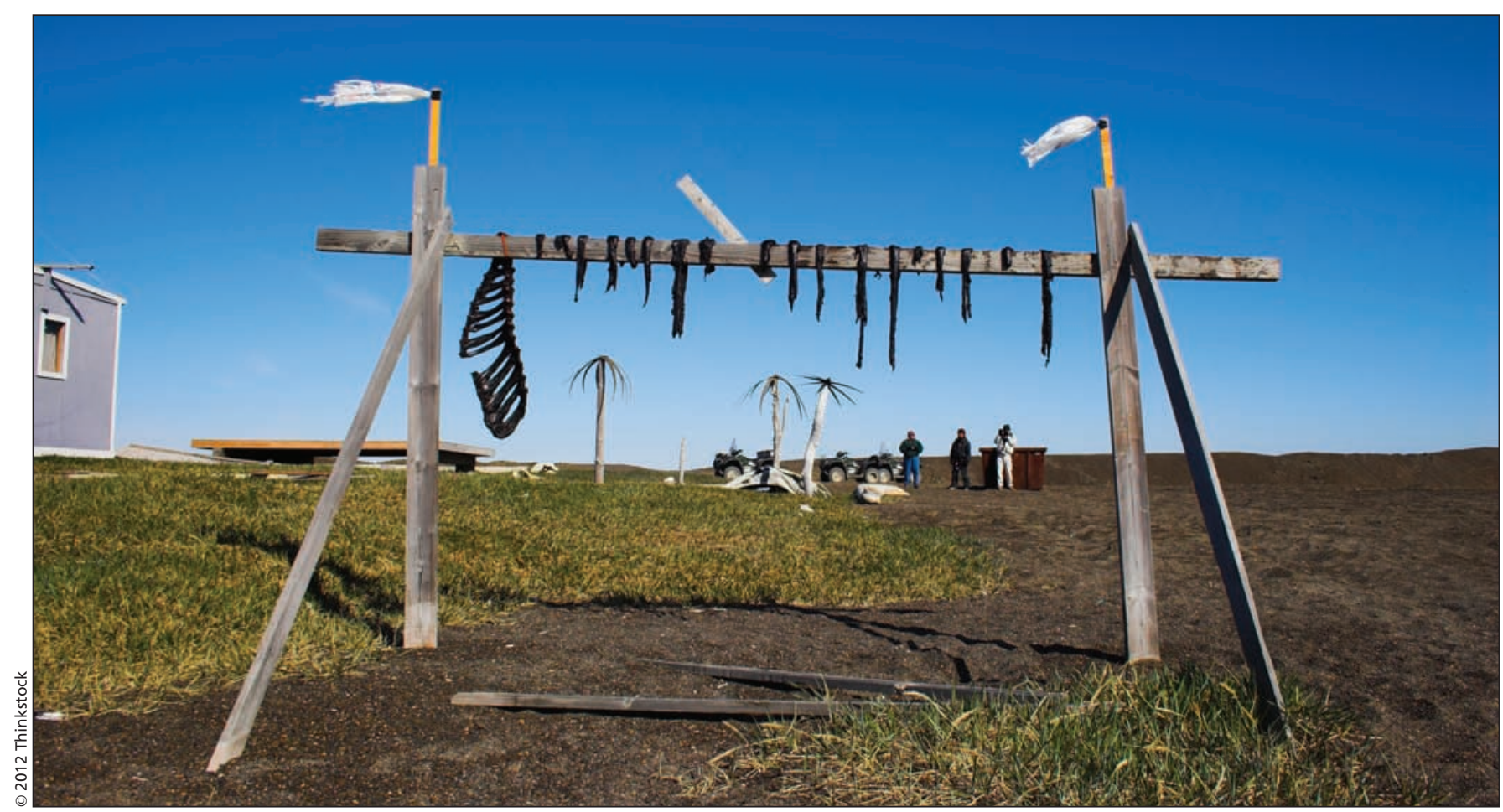

Climate change is altering the migratory routes of species like caribou and thus the diets of the Inuit people. Here, caribou meat is hung out to dry into jerky. 
nities where there is only one store, you will see an aisle of assorted chips, assorted pop. Diabetes did not exist in my grandmother's day because sugar was new to them. That was only two generations ago." According to Statistics Canada's 2006 Aboriginal Peoples Survey, the diabetes rate in Inuit adults aged 15 and over is $4 \%$, about the same as in the rest of Canada.

That will only be exacerbated as climate change affects things like migratory patterns, says Curtis Scurr, an analyst with the Environmental Stewardship Unit of the Assembly of First Nations. "The migration routes of various nutritional food species - caribou, geese, fishery habitats - are changing. Some are moving further south, so it's really affecting the traditional diets of communities across Canada."

Such changes are resulting in social and psychological disruption, says Ashlee Cunsolo Willox, who is conducting doctoral research on the effects of climate change.

Because of low ice levels over the past two winters, many families were unable to go caribou hunting in Nunatsiavut and there was a great risk of skidoos breaking through the ice, Cunsolo Willox notes. With such changes to their cultural traditions, many northern residents are depressed and distressed, resulting in a higher incidence of domestic violence, alcohol or drug abuse, and suicide, she says. Unpublished 2005 data from Health Canada provided by the Inuit Tapiriit Kanatami indicates the suicide rate for the Inuvialuit Settlement Region, Nunavut and Nunatsiavut, is 11 times higher than the rate in the rest of Canada, she adds.

"People were reporting either they themselves or people they knew from this disruption to climate were more likely to have suicidal thoughts and suicidal behavior," Cunsolo Willox asserts.
"It seems that climate change is the last straw or trigger on other aspects of mental health. People were saying they had all of these other issues and the thing that kept them together was to be able to go on the land and travel and go to cabins. Not being able to do that was the breaking point."

Climate change will also likely introduce new social ills in the Arctic, says Neil Melvin, programme director for the Stockholm International Peace Research Institute's Armed Conflict and Conflict Management Programme. "There is going to be a lot more human activity in the Arctic. Port towns are notoriously unruly places and criminal entry points for smuggling, drugs and new drug routes opening up. So there are issues to do with policing, rescue services, security." - Becky Rynor, Ottawa, Ont.

CMAJ 2012. DOI:10.1503/cmaj.109-4053 